\title{
Psychometric Properties of a Turkish Version of the Oral Health Impact Profile for Edentulous Patients: Validity, Reliability and Comparison with A Visual Analogue Scale
}

\author{
Ikbal Leblebicioglu Kurtulus(0000-0001-9122-9852) ${ }^{\alpha}$, Ravza Eraslan(0000-0001-2345-6789) ${ }^{\alpha}$, Kerem Kilic(0000-0003-2474-7865) ${ }^{\alpha}$, \\ Gozde Erturk Zararsiz(0000-0002-5495-7540) ${ }^{\beta}$, Zeynep Karacalar(0000-0002-2229-8354) ${ }^{\alpha}$
}

Selcuk Dent J, 2021; 8: 768-775 (Doi: 10.15311/selcukdentj.834577)

Basvuru Tarihi: 02 Aralık 2020 Yayına Kabul Tarihi: 22 Aralık 2020

\begin{abstract}
Psychometric Properties of a Turkish Version of the Oral Health Impact Profile for Edentulous Patients: Validity, Reliability and Comparison with A Visual Analogue Scale

Background: OHIP-EDENT is a shortened version of the Oral Health Impact Profile instrument The purpose of this study was to develop and evaluate the Turkish version of it (OHIP-EDENT-TR) for the elderly population in Turkey.

Methods: A total of 120 edentulous patients (72 males, 48 females; mean age $65.59 \pm 7.61$ years) who had complete prostheses were included in the study. The patients completed the OHIP-EDENT-TR, which was translated during this study, and a visual analogue scale $(100 \mathrm{~mm})$ twice at an interval of 3 months. Cronbach's alpha was used to measure the internal consistency of the summary scores for the OHIP-EDENT-TR. The interclass correlation coefficient and 95\% confidence interval of the summary scores for the OHIP-EDENT-TR and its subscales were calculated.
\end{abstract}

Results: The lowest and highest reliabilities were obtained for questions $7(n=120, \alpha=0.888)$ and $2(\alpha=0.931)$, respectively. The reliability of the summary scores for the OHIP-EDENT-TR was good $(\alpha=0.903)$. There was a significant relationship between the OHIP. EDENT-TR scale and visual analogue scale scores $(p<0.001)$. These values were indicative of fair-to-excellent convergent validity.

Conclusion: The Turkish version of OHIP EDENT (OHIP-EDENT-TR) is a reliable, valid and applicable scale for evaluating oral health related quality of life in the Turkish elderly patients.

\section{KEYWORDS}

OHIP-EDENT, OHIP-EDENT-TR, Validity, Reliability, VAS

To evaluate treatment results in evidence-based dentistry, the use of questionnaires addressing patient satisfaction has come to the fore. In the evaluation of their treatments, the opinions of patients should be evaluated as a variable of treatment success., ${ }^{1,2}$ Quality of life (QoL) questionnaires are really effective scales which are evaluating a patient's daily activities. ${ }^{3}$

Among the various oral health-related QoL (OHRQoL) instruments used, the Oral Health Impact Profile (OHIP) has been developed to provide a comprehensive measurement of reported dysfunction, discomfort, and disability due to the oral condition. ${ }^{4}$ Consisting of 49 questions, the OHIP provides detailed information when

\section{Öz}

Dişsiz Hastalar Için Ağız Sağlığı Etki Profilinin Türkçe Versiyonunun Psikometrik Özellikleri: Geçerlilik, Güvenilirlik Ve Görsel Analog Ölçek Ile Karşılaştırma

Amaç: OHIP-EDENT, Ağız Sağlığı Etki Profili aracının kısaltılmış bir versiyonudur. Bu çalışmanın amacı, Türkiye'deki yaşlı nüfus için bu aracın Türkçe versiyonunu (OHIP-EDENT-TR) geliştirmek ve değerlendirmektir.

Gereç ve Yöntemler: Tam protez kullanan 120 dişsiz hasta (72 erkek, 48 kadın; ort. Yaş $65.59 \pm 7.61$ yıl) çalışmaya dahil edildi. Hastalar bu çalışma sırasında çevrilen OHIPEDENT-TR'yi ve bir görsel analog skalayı $(100 \mathrm{~mm}) 3$ ay arayla iki kez tamamladı. OHIP-EDENT-TR için özet puanların iç tutarırıı̆ını öıçmek için Cronbach alfa kullanıldı. OHIP-EDENT-TR ve alt ölçeklerinin özet puanlarının sınıflar arası korelasyon katsayısı ve \% 95 güven aralığı hesaplandı.

Bulgular: En düşük ve en yüksek güvenilirlik sırasıyla 7 . sorular $(n=120, \alpha=0.888)$ ve 2 . sorular $(\alpha=0.931)$ için elde edildi. OHIP-EDENT-TR için özet puanların güvenilirliği iyiydi ( $\alpha=0.903$ ). OHIP-EDENT-TR ölçeği ile görsel analog ölçek puanları arasında anlamlı bir ilişki vardı $(p<0.001)$. Bu değerler orta-mükemmel yakınsak geçerliliğin göstergesiydi.

Sonuç: OHIP EDENT'in (OHIP-EDENT-TR) Türkçe versiyonu; yaşı Türk hastalarda ağız sağlığı ile ilgili yaşam kalitesini değerlendirmek için güvenilir, geçerli ve uygulanabilir bir ölçektir.

\section{ANAHTAR KELIMELER}

OHIP-EDENT, OHIP-EDENT-TR, Geçerlilik, Güvenilirlilik, VAS

OHRQoL is the primary outcome in a clinical setting. ${ }^{5}$ However, using it takes time for both the clinician and the patient, and it may require extra effort for elderly patients. ${ }^{6}$

Among the various OHRQoL instruments, OHIP-14 is one of the most-used. ${ }^{3}$ The Turkish version, OHIP-14-TR, which was released by Balci et al. ${ }^{7}$, among others, may not detect developments in edentulous patients after examination because of the extent of the questions. ${ }^{7,8}$ The OHIP-EDENT is a shortened version of the OHIP consisting of 19 items targeting edentulous patients. Such a shortened version is a powerful tool to evaluate the

\footnotetext{
${ }^{\alpha}$ Erciyes University, Faculty of Dentistry, Department of Prosthodontics Kayseri, Turkey.

$\beta$ Erciyes University, Faculty of Medicine, Department of Biostatistics Kayseri, Turkey.
} 
impact of oral health on QoL for the elderly population. ${ }^{7,9}$ This tool is intended to measure this impact for patients using complete dentures; it is unique to edentulous patients and offers questions that address chewing capacity, eating pleasure, comfort and confidence in wearing dentures, and relationship issues with others. ${ }^{7}$.

Although the OHIP-14 and the OHIP with 49 questions were translated and approved, the Turkish version of the OHIP-EDENT was not approved for use. Including OHIP-EDENT in a national survey could be an opportunity to obtain data and produce information easily to inform health policy. In this context,, the aim of this study was to analyse and evaluate the reliability, validity, and intelligibility of a Turkish translation of the OHIP EDENT among 120 Turkish edentulous patients in order to provide an objective translation and a standard scale for future researches.

\section{MATERIALS AND METHODS}

\section{OHIP-EDENT-TR}

The study was started with the translation of the original OHIP-EDENT into Turkish with modern cultural adaptation techniques. ${ }^{10}$ Following this, the psychometric properties of the scale including evaluation of the reliability and validity of the scale in typical target populations were evaluated.

The OHIP-EDENT-TR was consisted of seven subscales as listed in Table 1.

Table 1.

\section{Turkish version of Oral Health Impact Profile for edentulous (OHIP-EDENT-TR)}

\begin{tabular}{|c|c|}
\hline & Protezlerinizi kullanmaya başladıktan sonra ... \\
\hline \multirow{3}{*}{$\begin{array}{l}\text { Fonksiyonel } \\
\text { Sinırlama }\end{array}$} & $\begin{array}{l}\text { 1) Ağız, diş ve protezleriniz yüzünden yiyecekleri çiğnemede } \\
\text { herhangi bir problem yaşadınız mı? }\end{array}$ \\
\hline & 2) Diş veya protezlerinizle yiyecekleri ısırabiliyor musunuz? \\
\hline & $\begin{array}{l}\text { 3) Protezlerinizin çenenize tam olarak uygun olmadığını hissediyor } \\
\text { musunuz? }\end{array}$ \\
\hline \multirow{4}{*}{ Fiziksel Ağrı } & 4) Ağzınızda hiç şiddetli bir ağı hissettiniz mi? \\
\hline & $\begin{array}{l}\text { 5) Ağız, diş veya protezlerinizden dolayı yiyecekleri yerken hiç } \\
\text { rahatsızlık duydunuz mu? }\end{array}$ \\
\hline & 6) Ağzınızda ağıının belirgin olduğu hassas noktalar oldu mu? \\
\hline & Sizi rahatsız eden protezleriniz oldu mu? \\
\hline \multirow{2}{*}{$\begin{array}{l}\text { Psikolojik } \\
\text { Rahatsızlık }\end{array}$} & Diş kaynaklı problemleriniz için endişelendiniz mi ? \\
\hline & Ağız, diş ve protez konusunda bilinçli misiniz? \\
\hline \multirow{3}{*}{ Fiziksel Engel } & $\begin{array}{l}\text { 10) Ağız, diş veya protezleriniz yüzünden herhangi bir yiyeceği } \\
\text { yemekten kaçındınız mı? }\end{array}$ \\
\hline & $\begin{array}{l}\text { 11) Protezlerinizle ilgili problemlerden dolayı yemek yiyemediğiniz oldu } \\
\text { mu? }\end{array}$ \\
\hline & $\begin{array}{l}\text { 12) Ağız, diş veya protez kaynaklı bir problem yüzünden yemeği yarıda } \\
\text { bıraktığınız oldu mu? }\end{array}$ \\
\hline \multirow{2}{*}{$\begin{array}{l}\text { Psikolojik } \\
\text { Yetersizlik }\end{array}$} & $\begin{array}{l}\text { 13) Ağız, diş veya protezlerinizdeki problemler yüzünden üzüntü } \\
\text { yaşadınız mı? }\end{array}$ \\
\hline & $\begin{array}{l}\text { 14) Ağız,diş veya protezlerinizdeki problemler yüzünden utandığınız } \\
\text { oldu mu? }\end{array}$ \\
\hline \multirow{3}{*}{ Sosyal Engel } & $\begin{array}{l}\text { 15) Ağız,diş veya protezlerinizdeki problemler nedeniyle dışarı } \\
\text { çıkmaktan kaçındığınız oldu mu? }\end{array}$ \\
\hline & $\begin{array}{l}\text { 16) Ağız,diş veya protezlerinizdeki problemlerden dolayı, eşinize veya } \\
\text { aile bireylerine karşı daha az hoşgörülü oldunuz mu? }\end{array}$ \\
\hline & $\begin{array}{l}\text { 17) Ağız,diş veya protezlerinizdeki i problemler nedeniyle başkalarına } \\
\text { karșı daha asabi oldunuz mu? }\end{array}$ \\
\hline \multirow{2}{*}{ Handikap } & $\begin{array}{l}\text { 18) Ağız,diş veya protezlerinizdeki problemler yüzünden insan } \\
\text { ilişkilerinizden eskisi kadar keyif almadığınız oldu mu? }\end{array}$ \\
\hline & $\begin{array}{l}\text { 19) Ağız, diş veya protezlerinizdeki problemler yüzünden genel olarak } \\
\text { hayatın daha az tatmin edici olduğunu hissettiniz mi ? }\end{array}$ \\
\hline
\end{tabular}

The patients were asked to fill the questionnaire by evaluating the rate of the oral health conditions which affected their daily life over the past month (0: never, 1 : almost never, 2: sometimes, 3: quite often, and 4: very often). ${ }^{7}$ The scores of the OHIP-EDENT-TR is between 0 and 76 , and the higher the score the lower the OHRQoL.

\section{Cross-cultural adaptation}

The intercultural adaptation of original English version of the OHIP-EDENT (OHIP-E) into Turkish language was made according to the recommendations of Beaton et al. ${ }^{11}$ A Turkish dentist with an advanced level English and a professional translator (Turkish-English) translated the questionnaire into Turkish. These two translated versions were evaluated by three dentists from the Erciyes University, Dentistry Faculty, Department of Prosthodontics and a new combined translation questionnaire was prepared. The participants of the evaluating group were all Turkish citizens and were in an advanced level in English. The final combined version of the questionnaire was again translated into English by two native English speaking professional translators who had not seen the original version of the OHIP-E. The final version of the questionare was finally evaluated by an expert committee consisted of a linguist, two healthcare professionals, a methodologist and an interpreter in order to finalize the translation. The finalised Turkish version was later tested in Erciyes University Faculty of Dentistry Department of Prosthodontics and was called the OHIP-EDENT-TR.

\section{Patients}

A total of 120 edentulous patients (72 males, 48 females; mean age $65.59 \pm 7.61$ years) were included in the study). The patients were using their upper and lower complete dentures at least five years which were made in our faculty. Informed consent was obtained from all subjects. The study protocol was approved by the Erciyes University's Ethics Committee.

The patients completed the OHIP-EDENT-TR twice at a 3-month interval. A visual analogue scale (VAS) was also used to evaluate the content validity of the scale, also twice with a 3-month interval in order to verify the precision of the scale in measuring the properties for which it was designed. We calculated the interclass correlation coefficient (ICC) and 95\% confidence interval $(\mathrm{Cl})$ of the summary scores for the OHIP and its various subscales. 


\section{Reliability}

The reliability of the OHIP-EDENT-TR was tested by using the ICC together with repeated interviews with all patients and the test-retest method. We calculated the ICCs, based on a one-way analysis of variance, and $95 \%$ Cls of the summary scores for the OHIPEDENT and its seven subscales.

\section{Statistical analysis}

We evaluated the internal consistency of the scale and the homogeneity of its seven dimensions using Cronbach's alpha coefficient; additivity was evaluated using the Tukey additivity test; the sufficiency of the sample size was evaluated with the Kaiser-MeyerOlkin (KMO) test; factorability was evaluated with the Bartlett test; and the factor structure was determined through main factors analysis with the varimax method used as the factor rotation method. The construct validity of the scale was evaluated using the Mann-Whitney $U$ and Spearman correlation analyses. Two independent groups were compared with the Mann-Whitney $U$ test. The reliability of the scale was determined using the test-retest method, intragroup correlation coefficients, and Student's t-test for matched subjects. The relationships among numerical data were analysed with the Pearson or Spearman correlation analysis tests; $p<0.05$ was considered statistically significant. The median and 25th and 75th percentile nonparametric distribution of each variable's data were evaluated using the Shapiro Wilk normality test and $\mathrm{Q}-\mathrm{Q}$ graphs. All analyses were conducted using TURCOSA (Turcosa Analytics Ltd. Co., Kayseri, Turkey; www.turcosa.com.tr) statistical software.

\section{RESULTS}

\section{Reliability}

The lowest and highest reliabilities were obtained for questions 7 ( $n=120, \alpha=0.888$ ) and $2(\alpha=0.931$; Table 2), respectively. The reliability of the summary scores for the OHIP-EDENT-TR was also good $(\alpha=$ 0.903 ). For test-retest reliability, the ICC and $95 \% \mathrm{Cl}$ were calculated from data obtained from three subjects, excluding one subject whose consent was not obtained for retesting; the results are listed in Table 3. The lowest and highest ICCs were obtained for factors 1 (0.876) and 3 (0.925), respectively.
Table 2.

Factor analysis results for Ohip-Edent-TR

\begin{tabular}{|c|c|c|c|c|c|}
\hline İtem & Mean & SD & $\begin{array}{l}\text { Corrrected } \\
\text { item-total } \\
\text { correlation }\end{array}$ & $\begin{array}{l}\text { Croncbach's } \\
\text { alpha if item } \\
\text { deleted }\end{array}$ & $\begin{array}{l}\text { Factor } \\
\text { loading }\end{array}$ \\
\hline \multicolumn{6}{|l|}{ Factor1 } \\
\hline 1-Q2 & 16641 & 223610 & 0.605 & 0.931 & 0.782 \\
\hline 2-Q7 & 17950 & 167779 & 0.840 & 0.888 & 0.776 \\
\hline 3-Q19 & 18275 & 172235 & 0.770 & 0.891 & 0.772 \\
\hline 4-Q5 & 17966 & 169965 & 0.766 & 0.891 & 0.758 \\
\hline $5-Q 3$ & 17775 & 173033 & 0.651 & 0.894 & 0.721 \\
\hline 6-Q18 & 18292 & 173973 & 0.734 & 0.892 & 0.721 \\
\hline 7- Q8 & 18267 & 173676 & 0.722 & 0.892 & 0.690 \\
\hline 8-Q1 & 17750 & 174155 & 0.627 & 0.895 & 0.573 \\
\hline \multicolumn{6}{|l|}{ Factor2 } \\
\hline 9-Q16 & 18791 & 189175 & 0.467 & 0.900 & 0.842 \\
\hline 10-Q15 & 18792 & 185595 & 0.586 & 0.898 & 0.765 \\
\hline 11-Q14 & 18608 & 182509 & 0.588 & 0.897 & 0.763 \\
\hline 12-Q17 & 18616 & 182575 & 0.631 & 0.896 & 0.663 \\
\hline \multicolumn{6}{|c|}{ Factor 3} \\
\hline $13-\mathrm{Q} 4$ & 18316 & 182437 & 0.540 & 0.898 & 0.821 \\
\hline 14-Q6 & 18366 & 177898 & 0.679 & 0.894 & 0.739 \\
\hline $15-\mathrm{Q} 13$ & 18358 & 171005 & 0.838 & 0.889 & 0.562 \\
\hline 16-Q12 & 18358 & 176097 & 0.703 & 0.893 & 0.547 \\
\hline 17-Q11 & 18250 & 173920 & 0.747 & 0.892 & 0.486 \\
\hline $18-\mathrm{Q} 10$ & 18183 & 176252 & 0.641 & 0.895 & 0.480 \\
\hline \multicolumn{6}{|l|}{ Factor4 } \\
\hline 19-Q9 & 16241 & 206655 & 0.230 & 0.917 & 0.874 \\
\hline
\end{tabular}

Table 3.

Internal consistency and test-retest reliability between the OHIP-EDENT-TR

\begin{tabular}{|c|c|c|c|}
\hline Subscale & Croncbach's alfa & Test-retest (ICC) & $95 \% \mathrm{Cl}$ \\
\hline Factor1 & & & \\
\hline 1-Q2 & \multirow{8}{*}{0.799} & \multirow{8}{*}{0.876} & \multirow{8}{*}{$(0.842-0.907)$} \\
\hline 2-Q7 & & & \\
\hline 3-Q19 & & & \\
\hline 4-Q5 & & & \\
\hline $5-Q 3$ & & & \\
\hline 6-Q18 & & & \\
\hline 7- Q8 & & & \\
\hline 8-Q1 & & & \\
\hline Factor2 & \multirow{5}{*}{0.832} & \multirow{5}{*}{0.905} & \multirow{5}{*}{$(0.877-0.929)$} \\
\hline 9-Q16 & & & \\
\hline 10-Q15 & & & \\
\hline 11-Q14 & & & \\
\hline $12-Q 17$ & & & \\
\hline Factor 3 & & & \\
\hline $13-Q 4$ & \multirow{6}{*}{0.881} & \multirow{6}{*}{0.925} & \multirow{6}{*}{$(0.904-0.944)$} \\
\hline 14-Q6 & & & \\
\hline $15-Q 13$ & & & \\
\hline 16-Q12 & & & \\
\hline $17-\mathrm{Q} 11$ & & & \\
\hline $18-Q 10$ & & & \\
\hline \multicolumn{4}{|l|}{ Factor4 } \\
\hline 19-Q9 & 0.917 & 0.903 & $(0.875-0.926)$ \\
\hline
\end{tabular}




\section{Content validity}

There was a significant relationship between the OHIPEDENT-TR scales and the VAS scores $(p<0.001)$, with the relationship in the negative direction $(-0.914$; Table 4).

Table 4.

Convengent validity of the OHIP-EDENT-TR correlation between subscale scores with visual analogue scale (VAS)

\begin{tabular}{lll}
\hline Variable & OHIP & \\
\hline & $\mathbf{r}$ & $\mathbf{p}$ \\
\hline VAS & -0.914 & $<0.001$ \\
\hline Age & -0.034 & 0.709 \\
\hline
\end{tabular}

The KMO test result was 0.887 , and Bartlett's test of sphericity was measured as 1739.897 (df $=171, \mathrm{p}<$ 0.001) for the OHIP-EDENT-TR. All these results indicated a sufficiently significant correlation to perform a factor analysis. The results of the factor analysis for all subscales were listed in Table 2. Factor loadings above 0.40 were noted for all items. A total of $70.916 \%$ of the variance could be accounted for by four factors extracted from the factor analysis. Significant correlations were found between the OHIP-EDENT-TR and VAS as indicated by total and subscale scores of the corrected item total correlations (respectively; $0.605-0.840,0.467-0.631,0.540-0.838$ and 0.917 ). These values were indicative of fair-to-excellent convergent validity.

Gender distribution is shown in Table 5.

Table 5.

\section{Gender distrubution}

\begin{tabular}{|clll}
\multirow{2}{*}{ Variable } & \multicolumn{2}{c}{ GENDER } & \\
\cline { 2 - 4 } & $\begin{array}{l}\text { Female Median } \\
(25 p-75 p)\end{array}$ & $\begin{array}{l}\text { Male Median (25p- } \\
75 p)\end{array}$ & $p$ \\
\hline OHIP-EDENT-TR & $17.00(8.25-33.50)$ & $11.00(8.25-24.75)$ & 0.152 \\
\end{tabular}

\section{DISCUSSION}

The validity and reliability of questionnaires translated from other languages should be investigated primly. ${ }^{11}$ The successful translation and adaptation of these questionnaires is a difficult task; it is not easy to translate from the original source language without the loss of outcome measurements. ${ }^{10}$ In this study, literature supported international norms were followed to make the original OHIP-EDENT could be used for Turkish patients without any loss of outcome criteria. ${ }^{10}$

According to the study's results, the OHIP-EDENT-TR showed good reliability and validity. The lowest alpha value obtained was for question 2 (alpha $=0.888)$, and even this was within acceptable limits. ${ }^{12}$ In fact, we report here higher alpha values than those of the Portuguese and Nepalese version, similar to the Japanese one, although lower than the Chinese one. .,9,13,14 Because Cronbach's alpha coefficient is partially affected by the sample size, this finding may be due to the difference in sample size between different studies. The sample size of the present study was larger than for the Portuguese or Nepalese version, similar to the Japanese one, and smaller than the Chinese one.6, ${ }^{6,13,14}$ Thus, the reliability of this study could be more accurate than the above researches with smaller sample sizes.

The results of the study showed the good internal consistency reliability of the OHIP-EDENT-TR. For test-retest reliability, a definite time interval was not determined experimentally, and a 3-month interval between tests was deemed appropriate..$^{15}$ The testretest reliabilities of the OHIP-EDENT-TR and its subscales were between good and excellent. The values obtained were higher than for the Portuguese, Chinese, and Japanese versions. .,9,14 $^{6}$ These findings emphasise that the OHIP-EDENT-TR is a reliable and stable device.

In this study, if the patients' satisfaction with their denture was high, the overall OHIP-EDENT-TR score was low, which shows concurrent validity. In addition, a relationship was found between the OHIP-EDENT-TR scale and VAS scores, which indicates the content validity of the OHIP-EDENTTR. In a study by Sato et al. ${ }^{6}$, the correlation coefficient between the summary scores for the OHIP-EDENT-J (OHIP-EDENT Japanese version) and the degree of satisfaction with dentures (100 $\mathrm{mm}$ VAS) was calculated, and they found similar results to this study.

He et al. ${ }^{14}$ reported that the KMO test led to the removal of five factors in their study. Possebon et al. ${ }^{16}$ also suggested that the OHIP-EDENT should be grouped in three domains ("physical impact", "psychological impact", and "social impact") instead of the seven originally proposed. Moreover, their results suggested that those three factors present a satisfactory explanation of the OHRQoL construct. Consistent with the results of the above studies, in the present study, the KMO test led to the removal of four factors from the factor analysis. As Possebon et al. ${ }^{16}$ noted in their study earlier, following researches perform a confirmatory factor analysis of the translated version of OHIP-EDENT to assess whether the four-factor model fits the data.

The limitations of this study are the limited number of patients included, not investigating the responsiveness of OHIP-EDENT-TR, and that the study was limited to one specific geographic region. Longitudinal studies with a greater number of subjects investigating the responsiveness of the OHIP-EDENT-TR are required. The study was 
conducted in a specific region (Central Anatolia) that might not be representative of the Turkish population.

The OHIP-EDENT-TR resulting from the study showed satisfactory psychometric properties. The reliability and construct validity of the questionnaire were acceptable. The scale can be used in international and intercultural researches evaluating OHRQoL of elderly edentulous patients. In addition, the content validity of the OHIPEDENT-TR has been proven in its comparison with the VAS scale.

\section{CONCLUSION}

The OHIP-EDENT-TR, an OHRQoL questionnaire consisting of 19 questions, was applied to targeted edentulous patients and demonstrated good reliability and validity. In addition, the content validity of the OHIP-EDENT-TR has been proven in a comparison with a VAS scale. 


\section{REFERENCES}

1. Awad MA, Feine JS. Measuring patient satisfaction with mandibular prostheses. Community Dent Oral Epidemiol 1998;26:400-5.

2. Zani SR, Rivaldo EG, Frasca LC, Caye LF. Oral health impact profile and prosthetic condition in edentulous patients rehabilitated with implantsupported overdentures and fixed prostheses. J Oral Sci 2009;51:535-43.

3. Slade GD, Strauss RP, Atchison KA, Kressin NR, Locker D, Reisine ST. Conference summary: assessing oral health outcomes--measuring health status and quality of life. Community Dent Health 1998;15:3-7.

4. Slade GD. Derivation and validation of a shortform oral health impact profile. Community Dent Oral Epidemiol 1997;25:284-90.

5. Leon S, Correa-Beltran G, De Marchi RJ, Giacaman RA. Ultra-short version of the oral health impact profile in elderly Chileans. Geriatr Gerontol Int 2017; 17:277-85.

6. Sato Y, Kaiba Y, Yamaga E, Minakuchi S. Reliability and validity of a Japanese version of the Oral Health Impact Profile for edentulous subjects. Gerodontology 2012;29:e1033-7.

7. Allen F, Locker D. A modified short version of the oral health impact profile for assessing healthrelated quality of life in edentulous adults. Int $\mathrm{J}$ Prosthodont 2002;15:446-50.

8. Balci N, Alkan N, Gurgan CA. Psychometric properties of a Turkish version of the oral health impact profile-14. Niger J Clin Pract 2017;20:1924.

9. Souza RF, Patrocinio L, Pero AC, Marra J, Compagnoni MA. Reliability and validation of a Brazilian version of the Oral Health Impact Profile for assessing edentulous subjects. J Oral Rehabil 2007;34:821-6.

10.Guillemin F, Bombardier C, Beaton D. Crosscultural adaptation of health-related quality of life measures: literature review and proposed guidelines. Journal of clinical epidemiology 1993;46:1417-32.

11.Beaton DE, Bombardier C, Guillemin F, Ferraz MB. Guidelines for the process of cross-cultural adaptation of self-report measures. Spine (Phila Pa 1976) 2000;25:3186-91.

12. Moss S, Patel P, Prosser H, Goldberg D, Simpson $\mathrm{N}$, Rowe $\mathrm{S}$, et al. Psychiatric morbidity in older people with moderate and severe learning disability. I: Development and reliability of the patient interview (PAS-ADD). $\mathrm{Br} \mathrm{J}$ Psychiatry 1993;163:471-80.

13. Shrestha B, Niraula SR, Parajuli PK, Suwal P, Singh RK. Reliability and Validity of a Nepalese Version of the Oral Health Impact Profile for Edentulous Subjects. J Prosthodont 2018;27:41620.
14. He SL, Wang JH. Reliability and validity of a Chinese version of the Oral Health Impact Profile for edentulous subjects. Qual Life Res 2015;24:1011-6.

15. Terwee CB, Bot SD, de Boer MR, van der Windt DA, Knol DL, Dekker J, et al. Quality criteria were proposed for measurement properties of health status questionnaires. J Clin Epidemiol 2007;60:3442.

16.Possebon A, Faot F, Machado RMM, Nascimento GG, Leite FRM. Exploratory and confirmatory factorial analysis of the OHIP-Edent instrument. Braz Oral Res 2018;32:e111.

Corresponding Author:

Ikbal LEBLEBICIOGLU KURTULUS

Erciyes University

Faculty of Dentistry

Department of Prosthodontics

Kayseri, Turkey

Phone : +90 5065355190

E-mail : ikbal_leblebicioglu@hotmail.com 